\title{
ANTICANCER ACTIVITY OF MANGOSTEEN PERICARP DRY EXTRACT AGAINST MCF-7 BREAST CANCER CELL LINE THROUGH ESTROGEN RECEPTOR -a
}

\author{
Agustina Setiawati ${ }^{1}$, Florentinus Octa Dika Riswanto ${ }^{1}$, Sri Hartati Yuliani ${ }^{1}$, \\ Enade Perdana Istyastono ${ }^{2}$
}

1Faculty of Pharmacy, Sanata Dharma University, Yogyakarta 55281, Indonesia

${ }^{2}$ Center for Environmental Studies Sanata Dharma University (CESSDU), Soropadan, Condongcatur, Yogyakarta 55283, Indonesia

Submitted: $12-03-2014$ Revised: 24-04-2014 Accepted: $16-06-2014$

*Corresponding author Agustina Setiawati

Email :

nina@usd.ac.id

\begin{abstract}
Breast cancer has very complex morphological and molecular characteristic. Estrogen receptor is one of biomarker in breast cancer progression, more than $60 \%$ breast cancer overexpress estrogen receptor a (ERa). Xanthone in Garcinia mangostana was investigated whether to have anticancer activity on colorectal, prostate, lung, blood and breast cancer. This research was focused on molecular mechanism of anticancer activity of mangosteen pericarp extract (MPE) on ER-a. This study used MCF-7 cells as a model of ER-a overexpressed breast cancer cells. Cytotoxic study towards MCF-7 cells was designed by using MTT test, further apoptotic induction assay was determined by double staining method using acridine orange and ethidium bromide. Extract molecular mechanism against breast cancer was assayed by immunocytochemistry. The MTT data was analyze using probit analysis to get $\mathrm{IC}_{50}$ then apoptosis and immunocytochemistry data were analysis qualitative analysis. MPE had strong cytotoxic activity on MCF-7 cells with $\mathrm{IC}_{50}$ of $45 \mu \mathrm{g} / \mathrm{mL}$ and morphological changes passed through apoptosis induction. The expression of ER-a in MPE treated cells was same as untreated cells. MPE did not suppress ER-a in both nucleus and cytoplasm. Anticancer activity of MPE misht be mediated by other gene involved in ER-a signaling pathway in breast cancer cells.
\end{abstract}

Key words: Breast cancer, Garcinia mangostana peel extract, estrogen receptor-a

\section{INTRODUCTION}

The most commonly diagnosed types of cancer among women in 2012 was breast cancer and breast cancer is expected to account for $29 \%(226,870)$ of all new cancer cases among women (Siegel et al., 2012). In 2005, 186.467 women suffered from breast cancer and 41.116 of them passed away because of these disease (CDC, 2009). Breast cancer was the major caused death cancer after cervical cancer in Indonesia (Idamardi, 2007).

Breast cancer has very complex morphological and molecular characteristic. One important marker of breast cancer for prognosis is estrogen reseptor (Giacinti et al., 2006). Approximately $60 \%$ of breast cancer over expressed estrogen receptor- $\alpha$ (ER- $\alpha)$ (Hanstein et al., 2004). The development of molecular targeted drug has great advanced to cancer therapy. ER- $\alpha$ is a molecular target to stop the progression of breast cancer.
Mangosteen (Garcinia mangostana Linn) pericarp contains various phytochemicals, primary xanthones. Xanthone isolated from mangosteen pericarps were: $\alpha$-mangostin, $\beta$ mangostin, $\gamma$-mangostin, mangostinone and 2 isoprenyl-1,7 dihydroxy-3-methoxy xanthone inhibited human leukimia HL60 cell line. Among them, $\alpha$-mangostin suppresed proliferation and induced apotosis of HL60 cells at $10 \mu \mathrm{M}$ (Matsumoto et al., 2003). Xanthone extract $(81 \% \quad \alpha$-mangostin and $\gamma$ mangostin) suppressed HT116 colon cancer cell (Aisha et al., 2012; Nabandith et al., 2004; Nakagawa et al., 2007). Xanthone: $\alpha$-mangostin, $\beta$-mangostin, $\gamma$-mangostin had anticancer activity on DLD-1 (Akao et al., 2008). Alpha mangostin had antiproliferative activity against SKBR3 human breast adenocarcinoma cell line (Moongkarndi et al., 2004) and MDA-MB231 (Kurose et al., 2012). This compound were also proof to reduce lymph node 
metastasis in xenograft model in Balb/c mice (Shibata et al., 2011). Garinia mangostana Linn pericarp extract has potential property to be chemopreventive agent against breast cancer.

This study investigated Garcinia mangostana pericarp extract (MPE) activity against breast cancer. Furthermore, it focused on $\mathrm{ER} \alpha$ as molecular target to suppress proliferation of MCF-7 cell, in vivo model of ER- $\alpha$ over expressed breast cancer cell.

\section{MATERIAL AND METHODS}

MPE was purchased from PT. Borobudur had $28.10 \% \alpha$-mangosteen. Fructus cortex of Garcinia mangostana Linn was extracted use $70 \%$ ethanol with ratio botanical extract 10:1 and used maltodextrine as its excipient. MCF-7 breast cancer cell line was cultured in Parasitology laboratory, Faculty of Medicine, Gadjah Mada University. Apoptosis staining using ethidium bromide and acridine orange from SIGMA. This research used US BIO estrogen receptor $\alpha$ primary antibody.

\section{MTT Cytotoxic Assay}

MCF-7 cells breast cancer cell line were subcultured until confluent. Approximately $5 \times 10^{3}$ cells were seeded into 96-well microplate and incubated at $37^{\circ} \mathrm{C}$ and $5 \% \mathrm{CO}_{2}$ for $24 \mathrm{~h}$. Medium was fride treatment control, were prepared from Tamofen $\AA$ tablet. MPE and tamoxifen were dissolved in DMSO as stock solutions. Various concentration of MPE and tamoxifen in medium were added into 96-well plate $100 \mu \mathrm{L}$ each and incubated in the same as previous condition for $24 \mathrm{~h}$. Each concentration was assayed in triplicates $(n=3)$. The medium culture was removed and rinsed by PBS 10\%, one hundreds micro Liter I $100 \mu \mathrm{L}$ contain $5 \mathrm{mg} / \mathrm{mL}$ MT'T was added into each well and incubated feather for $4 \mathrm{~h}$. Event, medium containing MTT was removed and $100 \mu \mathrm{L}$ SDS was added each well to dissolve the optical density of the resulting solution. The 96-well microplate was incubated for $24 \mathrm{~h}$ and avoid from light contact. Formazan crystals were detected by ELISA reader using $595 \mathrm{~nm}$ wavelength.

\section{Apoptosis Assay}

MCF-7 were seeded $5 \times 10^{4} / 100 \mu \mathrm{L}$ into coverslip in 24 -well plate, then adapted in $37^{\circ} \mathrm{C}$ and $5 \% \mathrm{CO}_{2}$ for $24 \mathrm{~h}$. Further, the medium was removed and rinsed by PBS. Seventeen and $34 \mu \mathrm{g} / \mathrm{mL}$ of MPE in Dulbecco's Modified Eayle's Medium were added into the well plate and incubated for $24 \mathrm{~h}$. These concentrations were determined fariure calculation $\mathrm{IC}_{50}$, as estimated concentration closed to $\mathrm{IC}_{50}$. The medium was removed from MCF-7 cells and rinsed by PBS. The coverslip was removed from well plate and transferred to object glass, and acridine orange-ethidium bromide (AE) was dropped at the coverslip. This slide was soon observed under flouresence microscope.

\section{Immunocytostaining of ER-a}

MCF-7 cells in DMEM was seeded $10^{5} / 100 \mu \mathrm{L}$ on 6 -well plate and incubated under $5 \% \mathrm{CO} 2$ for $24 \mathrm{~h}$. MPE in concentration of 17 and $34 \mu \mathrm{g} / \mathrm{mlL}$ were applied on cells and incubated for 24 hours. After incubation, cells was collected and washed in PBS. They were resuspended in DMEM and placed in object glass, fixated for $5 \mathrm{~min}$, incubated in $\mathrm{H}_{2} \mathrm{O}_{2}$ for 10-15min and then washed again using PBS. Monoclonal antibody anti ER- $\alpha$ was and incubated at least for an hour and washed three time using PBS. Secondary antibody of biotinylated goat anti-polyvalent was added and incubated at room temperature for $10 \mathrm{~min}$ and washed four times in PBS. DAB as chromogen the mistune was dropped and incubated for and 3-8min, washed using aquadest. Finally, hematoxylin solution was added and incubated for 3-4 minutes. This slides were dried and observed under light microscope. Expression of ER- $\alpha$ was showed by brown cell colour.

\section{Analysis}

The cytotoxic data of MPE and tamoxifen were analyzed by excel. $\mathrm{IC}_{50}$ was then calculated using probit analysis (Finney and Stevens, Any new references?

\section{RESULT AND DISCUSSION}

This study investigated another cytotoxic properties of Garcinia mangostana pericarp against breast cancer cell line. MCF-7 was used as in vivo model of over expressed ER- $\alpha$ cells. MPE and tamoxifen were dissolved into excess DMSO as inert solvent in cell culture. Cavalli et al. (2011) and Licciardi et al. (2010) showed that DMSO $2 \mu \mathrm{L}$ in volume $(2 \% \mathrm{v} / \mathrm{v})$ have no 


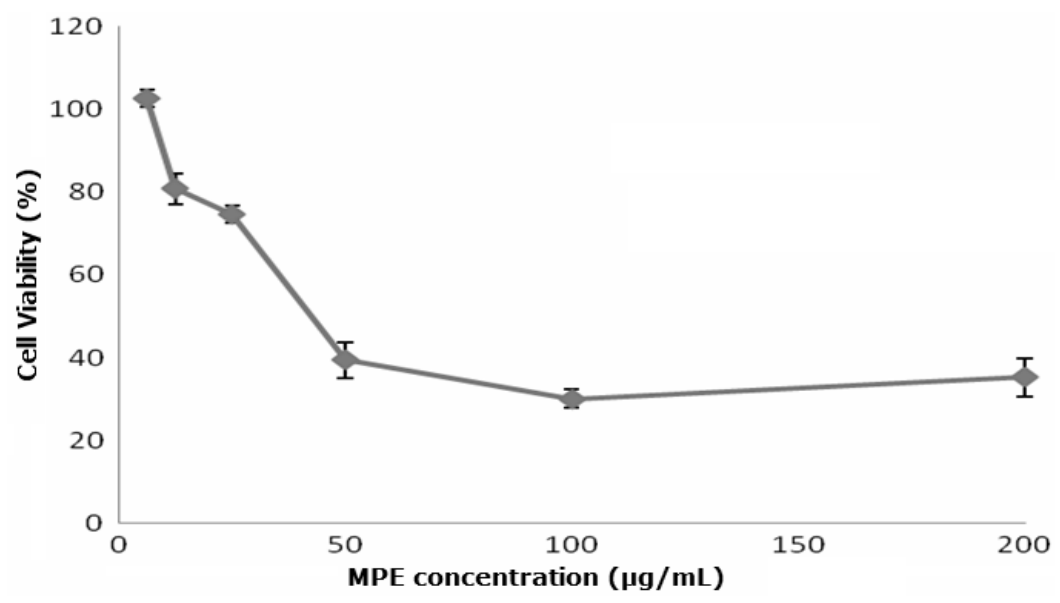

Figure 1. Effect of MPE on MCF-7 viability after 24 hour incubation
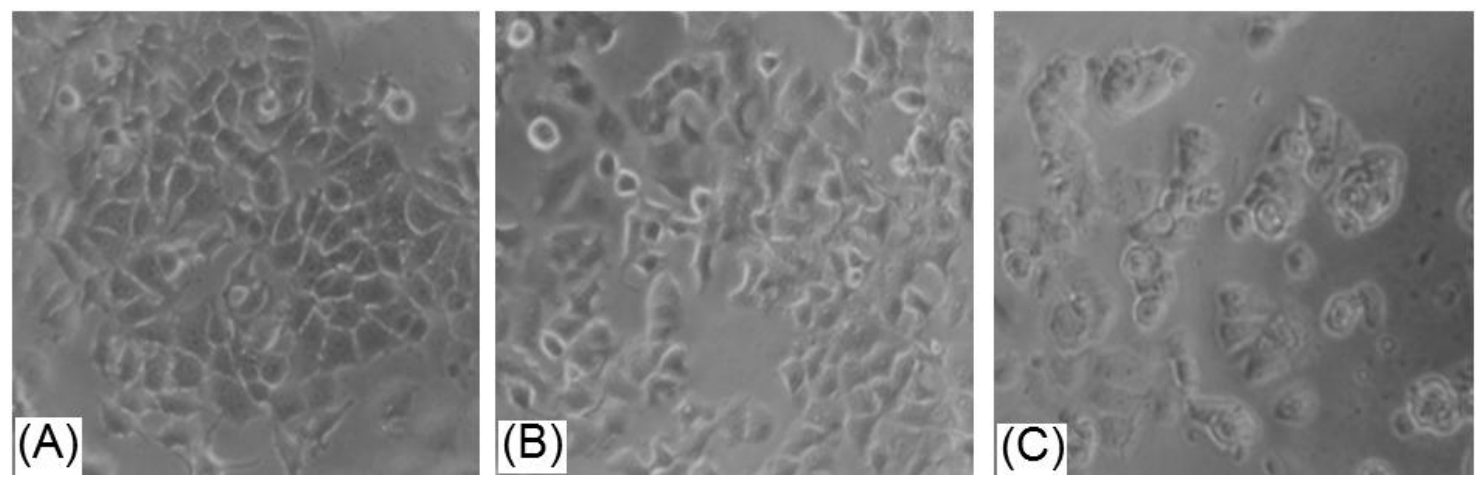

Figure 2. Effect of MPE and tamoxifen on MCF-7 morphology after 24h incubation (A) Untreated cells (B) $40 \mu \mathrm{g} / \mathrm{mL}$ MPE treated cells (C) $10-6 \mu \mathrm{g} / \mathrm{mL}$ tamoxifen treated cells.

cytotoxic activity against MCF-7 cells. This research used $0.02 \% \mathrm{v} / \mathrm{v}$ DMSO for MPE and oxifen. MTT was absorbed into living cells and converted into purple coloured-formazan complex by succinate dehydrogenase in mitochondria (Doyle and Grifith, 2000). MPE exhibit cytotoxic parabolic profile (Figure 1), probit analysis yielded MPE $\mathrm{IC}_{50}$ of $45 \mu \mathrm{g} / \mathrm{mL}$.

The urage of tamoxifen as positive control is a estrogen receptor $\alpha$ partial agonis, was regarded as first line drug in ER- $\alpha$ over expressed breast cancer treatment (Ao et al., 2011; Fowler et al., 2004). Tamoxifen, was also tested against MCF-7 cells by the same procedure. Tamoxifen had parabolic cytotoxic profile and had $\mathrm{IC}_{50} 47 \mu \mathrm{M}$ or equal to $12,65.10^{-}$ ${ }^{7} \mu \mathrm{g} / \mathrm{mL}$ by probit analysis. Tamoxifen had strong cytotoxic activity making $\mathrm{MCF}-7$ cells broken into debris but MPE (Figure 2). This could be explained that tamoxifen is pure chemical compound having spesific target on the cells. MPE also drived morphological changes in MCF-7 cells even it did not make the cells broken into debris. MPE contained various natural compounds so it did not have spesific target compared to THAT OFtamoxifen.

Assay then must be designed in other study to confirm molecular mechanism of MCF-7 cells. This study used double staining method using acridine orange and ethidium bromide. Viable cells were green and apoptotic cells were red. MPE showed apoptosis induction towards MCF-7 cells were dosedependent.

This research used apoptotic cells 17 and $34 \mu \mathrm{g} / \mathrm{mL} \mathrm{MPE}$ to investigate apoptotic staining. MCF-7 cells were orange and those 

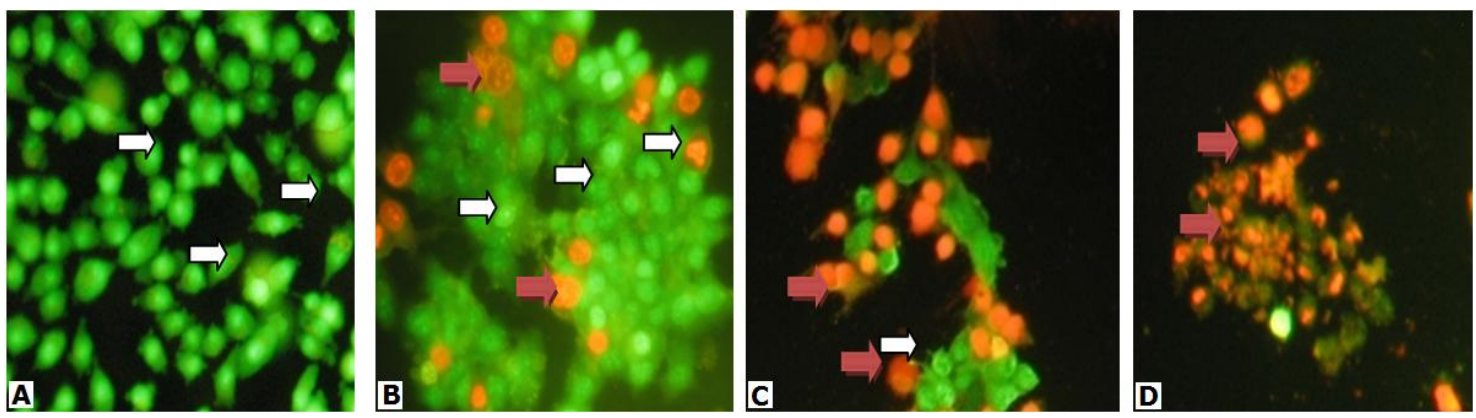

Figure 3. Apoptotic cells observation using double staining method under flourencence microscope using 400x magnification. (A)Untreated cells, (B)Cells treated $17 \mu \mathrm{g} / \mathrm{mL}$ MPE (Cpoint C: MPE concentration should be "cells treated $34 \mathrm{ug} / \mathrm{mL}$ MPE" (as described on the text) not 'cells treated $13 \mathrm{ug} / \mathrm{mL}^{\prime}$; (D) Cells treated $12,65 \cdot 10^{-7} \mu \mathrm{g} / \mathrm{mL}$ tamoxifen $\Rightarrow$ living cells; $\Rightarrow$ apoptotic cells.
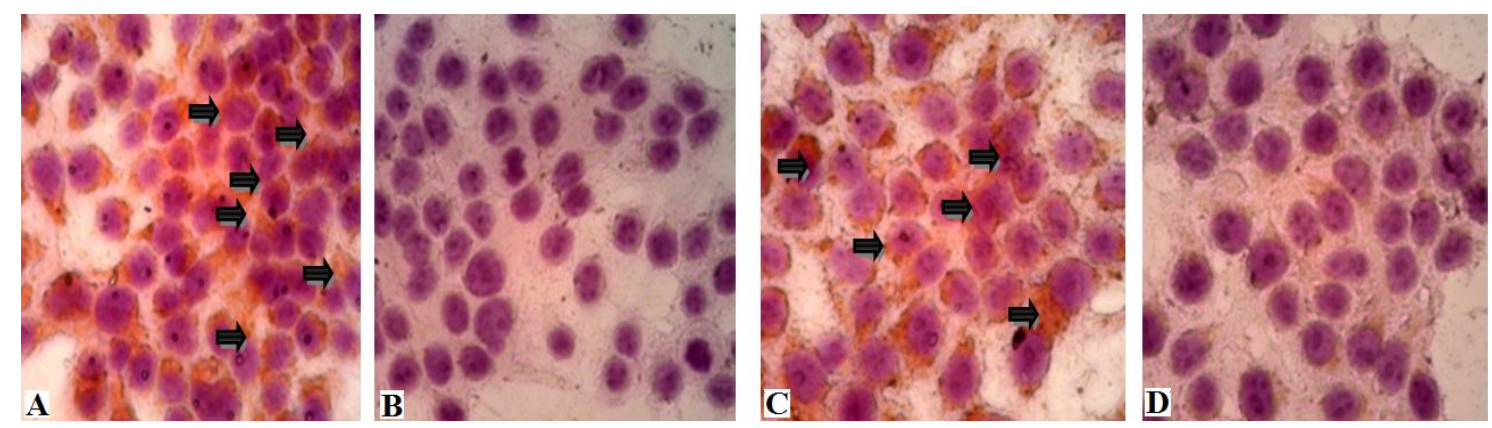

Figure 4. The observation of ER- $\alpha$ expression using immunocytochemistry method under light microscope using 400x magnification. (A)Untreated cells, (B) Untreated cells without antibody (C) $\mathrm{MPE} 17 \mu \mathrm{g} / \mathrm{mL}$ treated cells (D) tamoxifen $\Rightarrow$ expressed ER- $\alpha$

membrane integrity was disturbed (Figure 3). MPE has lower cytotoxic and apoptosis induction activity compare to that of tamoxifen, it might be due to complexity of MPE natural compound. These novel findings underline the benefit of in vitro study to elucidate molecular mechanisms of chemopreventive agent.

The molecular mechanism of apoptosis induction of MPE on ER- $\alpha$ was confirmed using immunocytochemistry method. Tamoxifen, a Selective Estrogen Receptor Modulators (SERMs), suppress ER- $\alpha$ expression. It down regulated ER- $\alpha$ by changing conformation of ER- $\alpha$ thus AF-2 domain is hide so AF-2 dependent co-activator hardly bind to the receptor (Brufsky, 2011). Untreated cells showed high expression of ER$\alpha$ both in nucleus and cytoplasm. ER- $\alpha$ is located in nucleus and cytoplasm near cell membrane in the absense and presence of estrogen (Cheskis et al., 2007). MCF-7 cells treated with $34 \mu \mathrm{g} / \mathrm{mL}$ made cells being fragmented into debris there fore this study $\mathrm{MPE}$ with concentratum of $17 \mu \mathrm{g} / \mathrm{ml}$, was used is detect ER- $\alpha$ expression. Even MPE had strong cytotoxic and apoptosis induction activity, it hardly suppressed ER- $\alpha$ expression. Is inhibited ER- $\alpha$ signaling pathway and might have other protein targets on MCF-7. There were 83 genes involved in ER- $\alpha$ signaling pathway in positive ER- $\alpha$ cell lines (Chisamore et al, 2009). Therefore, other genes involved in ER- $\alpha$ signaling pathway must be investigated.

\section{ACKNOWLEDGEMENT}

This work was funding by Internal Research Grant, Center for Research and Public Services Sanata Dharma University, Yogyakarta 


\section{REFERENCES}

Ao A., Morrison BJ., Wang H., Lopez A., Reynolds BA., Lu J., 2011, Response of Estrogen Receptor-Positive Breat Cancer Tumorspheres to Antiestrogen Treatments, 6(4): e18810.

Aisha AF., Abu-Salah KM., Ismail Z., Majid AMSA. 2012. In vivo and in vivo anticolon cancer effect of Garcinia mangostana xanthones extract. BMC Complementary and Alternative Medicine, 12: 104- 113

Akao Y., Nakagawa Y., Linuma M., Nozawa Y. 2008. Anti-Cancer Effects of Xanthones from pericarps of Mangosteen, Int. J. Mol. Sci. 9, 355 - 70 .

Brufsky. 2011. Undestanding the estrogen receptor signaling pathway: focus on current endocrine agent for breast cancer in postmenopausal women., Community Oncology, 8(8): 343- 352.

Cavalli A., Bisazza R., Bussano, 2011, Poly(amidoamine)-cholesterol conjugate nanoparticles obtained by electrospraying as novel tamoxifen delivery system, Journal of Drug Delivery, Article ID 587604, 9 pages.

Center for Disease Control and Prevention (CDC). 2009. Breast Cancer, available online at http://www.cdc.gov/cancer/ breast/, accesed on March 3, 2014.

Cheskis BJ., Greger JG., NagpalS., Freedman LP. 2007. Signaling by estrogens. J.Cell Physiol. 213: 610-617.

Chisamore MJ., Wilkisonm HA., Flores O., Chen JD. 2009. Estrogen-related receptor-a antagonist inhibits both estrogen receptor-positive and estrogen receptor-negative breast tumor growth in mouse xenograft, 8: 672- 681.

Doyle A. and Griffiths JB. 2000. Cell and Tissue Culture for Medical Research, John Willey \& Sons LTD, England.

Finney DJ., Stevens WL. 1948. A Table for Calculation of Working Probits and Weights in Probit Analysis, Biometrika, 35(1-2): 191- 201.

Flowler AM., Solodin N., Mara T., Preisler M., Zhang P., Lee AV, Alarid ET. 2004. Increases in estrogen receptor- $\alpha$ concentration in breast cancer cells promote serine 118/104/106independent AF-1 transactivation and growth in the absence of estrogen, FASEB Journal, 18: 81-93

Hanstein B., Djahansouzi S., Dall P., Beckmann MW., Bender HG. 2004. Insight into molecular biology of the estrogen receptor define novel therapeutic targets for breast cancer, 150: 243- 255.

Giacinti L., Claudio PP., Lopez M., Giordano A. 2006. Epigenetic Information and Estrogen Receptor Alpha Exoression in Breast Cancer. The Oncologist. 11(1): 1-8

Idamardi, 2007. Kanker Payudara, Yayasan Kanker Payudara Indonesia, Jakarta.

Kurose H., Shibata MA., Iinuma M., Otsuki Y. 2012. Alteration in Cell Cycle and Induction of Apoptotic Cell Death in Breast Cancer Cells Treated with $\alpha$ Mangostin Extracted in Mangosteen Pericarp, J Biomee and Biotec. 1-9

Licciardi G., Cavallaro M., Di Stefano G., Pitarresi, C., Fiorica G., Giammona. 2010. New self-assembling polyaspartylhydrazide copolymer micelles for anticancer drug delivery, Int Journal Pharm, 396(1-2):219-228.

Matsumoto K., Akao Y., Kobayashi E., Ohguchi K., Ito T., Tanaka T., Linuma M., Nozawa Y. 2003. Induction of Apoptosis by Xanthones from Mangosteen in Human Leukimia Cell Lines, J.Nat. Prod. 66: 1124- 1127.

Moongkarndi P., Kosem N., Kaslungka S., Luanratana O., Pongoan N., Neungton N. 2004. Antiproliferation, Antioxidation and Induction of Apoptosis by Garcinia mangostana (mangosteen) on SKBR3 human breast cancer cell line. J.Ethnopharmacol..90(1): 161-6.

Nabandith V., Suzui M., Kaneshiro T., Kinjo T., Matsumoto K., Akao Y., Linuma M., Yoshimi N., Inhibitory Effect of Crude Alpha-Mangostin. 2004. a Xanthone derivative, on two different categories of colon preneoplastic lesion induced by 1,2-dimethylhidrazine in rat. Asian Pac J Cancer Prev. 5(4): 433-8.

Nakagawa Y. Linuma M., Nozawa Y., Akao Y. 2007. Characteristized mechanism of $\alpha$ mangostin induced cell death: Caspaseindependent apoptosis with release of endonuclease- $G$ from mitochondria and 
increased miRNA-143 expression in human colorectal cancer DLD-1 cells. Bioorg.Med. Chem. 15: 5620- 5628.

Siegel R., Naishadham D., Jemal A. Cancer Statistics. 2012. CA Cancer J. Clin. 2012. $62: 10-29$.

Shibata MA., Linuma M., Morimoto J., Kurose H., Akamatsu A., Okuno Y., Akao Y., Otsuki. 2011. A-mangostin extracted from the pericarp of the mangosteen (Garcinia mangostana Linn) reduces tumor growth and lymph node metastasis in an immunocompetent xenograft model of metastatic mammary cancer carrying a p53 mutation, BMC Medicine, (9): 69.

Ueda J., Tezuka Y., Baskota AH., Tran QL., Tran QK., Hariyama Y., Saiki I., Kadota S., 2002. Antiproliferative Activity of Vietnamese Medicinal Plants. Biol.Pharm. Bull., 25(6): 753- 760. 